\title{
Tracing the colonization of Madeira and the Canary Islands by Drosophila subobscura through the study of the $r p 49$ gene region
}

\author{
M. Khadem, ${ }^{1}$ J. Rozas, ${ }^{2}$ C. Segarra, ${ }^{2}$ A. Brehm' ${ }^{1}$ and M. Aguadé*.2 \\ ${ }^{1}$ Departamento da Biologia, Universidade da Madeira, Funchal, Portugal \\ ${ }^{2}$ Departament de Genètica, Facultat de Biologia, Universitat de Barcelona, \\ Diagonal 645, E-08071 Barcelona, Spain, e-mail: aguade@porthos.bio.ub.es
}

Key words: Drosophila subobscura species cluster; rp49 gene region; colonization; Canary Islands; Madeira.

\begin{abstract}
Nucleotide variation at the nuclear ribosomal protein 49 (rp49) gene region has been analysed by fine restriction mapping in a sample of 47 lines from a population from Madeira. Five restriction-site (out of 37 sites scored) and 3 length polymorphisms have been detected, resulting in 14 different haplotypes. This population shows less variation than both continental and Canary Island populations. The population from Madeira shows some differentiation from mainland populations, which does not favor the idea of extensive migration between the continent and Madeira. Chromosomal and restriction-map variation of the $r p 49$ region in $D$. subobscura populations, together with data on sequence comparison of this nuclear region in $D$. guanche and $D$. madeirensis clearly indicate that the Canary Islands underwent at least two colonization events from the nearby continent. Although the data for Madeira are compatible with a single colonization event by a continental sample polymorphic for gene arrangements $\mathrm{O}_{3}$ and $\mathrm{O}_{3+4}$, an alternative scenario with at least two colonization events seems more likely.
\end{abstract}

\section{Introduction}

Drosophila subobscura is a Palearctic species that has recently colonized the American continent (Prevosti et al., 1988). The species has a wide distribution area

* Author for correspondence 
in Europe and it is also present in Northern Africa and Asia Minor (Krimbas, 1992). The Atlantic Ocean establishes the Western limit of the D. subobscura distribution in the Palearetic region. Nevertheless, the species is present in the Azores, Madeira and Canary archipelagos. These archipelagos have a volcanic origin and their geological history is rather well known (Galopin de Carvalho and Brandão, 1991; Carracedo, 1994). Additionally, in Madeira and the Canary Islands, D. subobscura ancestral populations gave rise to the extant endemic species $D$. madeirensis and D. guanche, respectively.

Natural populations of $D$. suhohscura covering a large range of its distribution area have been extensively studied by population geneticists. These studies have focused mainly on chromosomal and allozyme polymorphisms and thus the degree of genetic variability at these levels has been well characterized (Krimbas, 1992). More recently, data on the nucleotide variation in natural populations of $D$. subobscura have also been reported for mtDNA (Latorre et al., 1986; Afonso et al., 1990) and for the nuclear $r p 49$ (ribosomal protein 49) gene region (Rozas and Aguadé, 1994 and references therein).

The chromosomal polymorphism of $D$. subobscura populations from Madeira and the Canary Islands has been analysed and compared with that found in the nearest continental populations of Morocco and Southern Spain (Prevosti, 1972, 1974; Larruga et al., 1983). Madeira and Canary Islands populations are chromosomally well differentiated from those of the continent. In fact, the insular populations have a similar set of chromosomal arrangements and their level of chromosomal polymorphism is lower than in the continent (mainly for chromosomes $\mathrm{A}$ and $\mathrm{O}$ ). The most striking difference is the absence in Madeira and the Canary Islands of the $\mathrm{O}_{3+4+8}$ gene arrangement (with frequencies above $55 \%$ in Southern Morocco) and of the $\mathrm{O}_{3+4+7}$ arrangement (with frequencies above $70 \%$ in Southern Spain). From this observation, Prevosti (1974) inferred that the chromosomal polymorphism of the insular populations is a relict polymorphism corresponding to a period previous to the establishment of the rich chromosomal polymorphism exhibited by continental populations of $D$. subobscura.

The pattern of chromosomal polymorphism differentiation between Madeira, Canary Islands and continental populations of D. subobscura differs, however, from that detected by allozyme and mtDNA studies. Genetic distances between these populations, based on a large number of allozyme loci, indicate a strong differentiation of Canary Islands populations relative to both Madeira and continental populations. Moreover, Madeira populations exhibit a closer resemblance to continental than to Canary Islands populations (Larruga et al., 1983; Pinto et al., 1997). The same pattern of differentiation has been observed by restriction fragment length polymorphism analysis of the mtDNA (Afonso et al., 1990; Pinto et al., 1997).

The $r p 49$ gene region is the only nuclear region whose nucleotide variability has been studied in natural populations of $D$. subobscura. This gene is located in 
segment I (distal part) of the $\mathrm{O}$ chromosome very close to one of the breakpoints of inversion $\mathrm{O}_{3}$ (Aguadé, 1988; Rozas and Aguadé, 1990). This inversion, together with inversion $\mathrm{O}_{4}$, forms the $\mathrm{O}_{3+4}$ gene arrangement which is segregating in most natural populations of $D$. subobscura, and presents clear latitudinal clines both in the Old World and in the recently colonized Americas (Prevosti et al., 1988, 1990). According to the location of the $r p 49$ gene in different arrangements of the $\mathrm{O}$ chromosome, and to the effect of inversions in suppressing recombination, gene arrangements of the $\mathrm{O}$ chromosome can be grouped in different chromosomal classes (Rozas and Aguadé, 1991b). In continental populations, chromosomal classes $\mathrm{O}_{[3+4]}$ and $\mathrm{O}_{[S T]}$ are genetically differentiated for the $r p 49$ gene region. Nevertheless, no geographic differentiation has been detected in Europe for a given chromosomal class (Rozas and Aguadé, 1990; Rozas et al., 1995). Analysis of restriction-map variation at the $r p 49$ region has also been studied in a population from Tenerife, Canary Islands (Rozas and Aguadé, 1991a). Despite the lack of differentiation within $\mathrm{O}_{\{3+4\}}$ in the continent, the population from Tenerife, with several endemic haplotypes, is genetically differentiated from continental populations. This result indicates a rather strong isolation of the Canary Islands from continental populations, as previously revealed by chromosomal, allozyme and mtDNA studies.

However, the degree of differentiation of D. subobscura populations from Madeira relative to those from the Canary Islands and the continent has not been studied at the DNA level for nuclear genes. In this context, nucleotide variation at the rp 49 gene region has been analysed in a natural population of $D$. subobscura from Madeira and compared to variation in populations from both the continent and the Canary Islands. This study for the $r p 49$ region can shed some light on the history of $D$. subobscura populations from Madeira. In addition, it can contribute (together with previous data at the chromosomal, allozyme and mtDNA levels) to tracing the colonization of both Madeira and Canary Islands by D. subobscura ancestors, and therefore to explain the current situation in which extant populations of D. subobscura coexist with the endemic species $D$. guanche in the Canary Islands and $D$. madeirensis in Madeira.

\section{Materials and methods}

Fly samples

Forty-seven isofemale lines of D. subobscura were established upon collection at Agua de pena (Madeira) in 1994. One $F_{1}$ male from each line was crossed with virgin females from the balancer stock for the $\mathrm{O}$ chromosome $\mathrm{Va} / \mathrm{Ba}$ (Sperlich et al., 1977); succesive crosses were done as described by Rozas and Aguadé (1990) to obtain heterozygotes of the wild chromosome over the $B a$ chromosome. The gene arrangement for the $\mathrm{O}$ chromosome was determined for each line by observation of polytene chromosomes of salivary glands of third-instar larvae. 
Restriction-map analysis

DNA was extracted using a short isolation method (Kreitman and Aguadé, 1986). For each line, an approximately $1.6 \mathrm{~kb}$ fragment encompassing the $r p 49$ gene was PCR amplified as previously described (Rozas and Aguadé, 1993). After chloroform extraction and ethanol precipitation of the PCR products, they were digested with seven tetranucleotide-recognizing restriction enzymes: $A l u \mathrm{I}, D d e \mathrm{I}$, HaeIII, HhaI, MspI, Sau3AI and TaqI. Purification of digested DNA, electrophoresis, electroblotting and hybridization were carried out as described by Kreitman and Aguadé (1986), except that the amount of labelled probe was reduced. A $1.6 \mathrm{~kb} A v a \mathrm{I}-E c o \mathrm{RI}$ fragment isolated from $D$. subobscura, slightly larger than the amplified region, was used as probe. Restriction-site and length polymorphisms were scored as previously described (Rozas and Aguadé, 1990).

Haplotype and nucletotide diversity were estimated as $h$ (Nei and Tajima, 1981) and $\pi$ (Nei, 1987), respectively. Linkage disequilibrium between pairs of polymorphic restriction sites was measured by the $D^{\prime}$ parameter (Lewontin, 1964). Genetic distances between populations were estimated by the net number of nucleotide substitutions per sitc between subpopulations, $\delta_{\mathrm{st}}$ (Nei, 1982). These distances were used to build a UPGMA (unweighted pair-group method with arithmetic mean) tree using the MEGA program (Kumar et al., 1994). The genetic differentiation between populations was also measured by the $K_{\mathrm{s}}$ and $K_{\mathrm{st}}$ parameters (Hudson et al., 1992) from information of the restriction haplotype data. $K_{\mathrm{s}}$ is the weighted average of the average number of differences between sequences within populations, and $K_{\text {st }}$ is the proportion of nucleotide differences between populations.

\section{Results}

\section{Nucleotide variation in Drosophila subobscura from Madeira}

In the 47 lines studied, 5 out of the 37 restriction sites scored (20 in noncoding regions, and 15 and 2 in the rp49 and $\delta$-serendipity protein coding regions, respectively) were polymorphic (Tab. 1, Fig. 1). Four of these five polymorphisms have been previously detected in other continental populations of $D$. subobscura (Rozas et al., 1995); the new polymorphic site was located at position 325, and its rare variant observed in only one line. All five polymorphic sites were silent: four were detected in noncoding regions, and one in exon 2 of the $r p 49$ gene (the synonymous state of this polymorphism has been previously determined by sequencing, Rozas and Aguadé, 1993).

We also detected 3 length polymorphisms (ID2, ID6, and ID8, in Tab. 1) in noncoding regions: one in the 5 ' flanking region, one in the intron, and another one in the $3^{\prime}$ flanking region. These length polymorphisms (insertions-deletions ranging from 2 to 12 nucleotides) have been previously reported in other continental populations of this species (Rozas and Aguadé, 1990; Rozas et al., 1995). 
Table 1. Haplotype variation at the $r p 49$ region of the $D$. subobscura population from Madeira.

\begin{tabular}{|c|c|c|c|c|c|c|c|c|c|c|c|}
\hline $\mathrm{T}$ & $\mathrm{R}$ & $\mathrm{I} / \mathrm{D} 2$ & $\begin{array}{l}\text { Sau } 3 \mathrm{AI} \\
325\end{array}$ & $\begin{array}{l}\text { Hae III } \\
524\end{array}$ & $\begin{array}{l}\text { Dde I } \\
631\end{array}$ & $\begin{array}{l}\text { Hha I } \\
702\end{array}$ & I/D6 & $\begin{array}{l}\text { Taq I } \\
1260\end{array}$ & I/D8 & $\mathrm{O}_{\mathrm{ST}}$ & $\mathrm{O}_{3+4}$ \\
\hline 1 & 1 & -1 & - & - & - & + & 2 & + & - & 2 & 12 \\
\hline 2 & 1 & 0 & - & - & - & + & 2 & + & - & 1 & 2 \\
\hline 3 & 1 & -3 & - & - & - & + & 2 & + & - & & 3 \\
\hline 4 & 1 & -1 & - & - & - & + & 2 & + & 4 & & 3 \\
\hline 5 & 1 & -1 & - & - & - & + & 2 & + & 2 & & 2 \\
\hline 6 & 1 & 0 & - & - & - & + & 2 & + & 4 & & 6 \\
\hline 7 & 1 & -1 & - & - & - & + & 0 & + & - & & 1 \\
\hline 8 & 1 & -2 & - & - & - & + & 2 & + & - & & 1 \\
\hline 9 & 1 & -4 & - & - & - & + & 2 & + & - & & 1 \\
\hline 10 & 2 & -1 & - & - & + & + & 2 & + & - & & 5 \\
\hline 11 & 3 & -1 & - & + & - & + & 2 & + & - & & 3 \\
\hline 12 & 4 & -1 & - & - & - & - & 2 & + & 2 & 1 & 2 \\
\hline 13 & 5 & 0 & - & - & - & + & 2 & - & - & & 1 \\
\hline 14 & 6 & 0 & + & - & - & + & 2 & + & - & 1 & \\
\hline Tot & & & & & & & & & & 5 & 42 \\
\hline
\end{tabular}

Coordinates of polymorphic sites are from Figure 1. I/D indicates insertion/deletion. The plus $(+)$ and minus (-) signs indicate the presence and absence of a restriction site or an insertion/deletion. Length polymorphisms are indicated according to Rozas ct al. (1995). T, haplotype number. R, Restriction-site haplotype number.

Length polymorphism I/D2 was located in a region with tandem repeats of the motif GTT; it shows 5 length variants in this population, all differing by multiples of $3 \mathrm{bp}$. Previous sequence comparison of several variants of the $\mathrm{I} / \mathrm{D} 2$ polymorphism (Rozas and Aguadé, 1993) has shown that they differ in the number of copies of the basic repeat. This polymorphism can, therefore, be considered a microsatellite, and slipped-strand mispairing (Levinson and Gutman, 1987) would
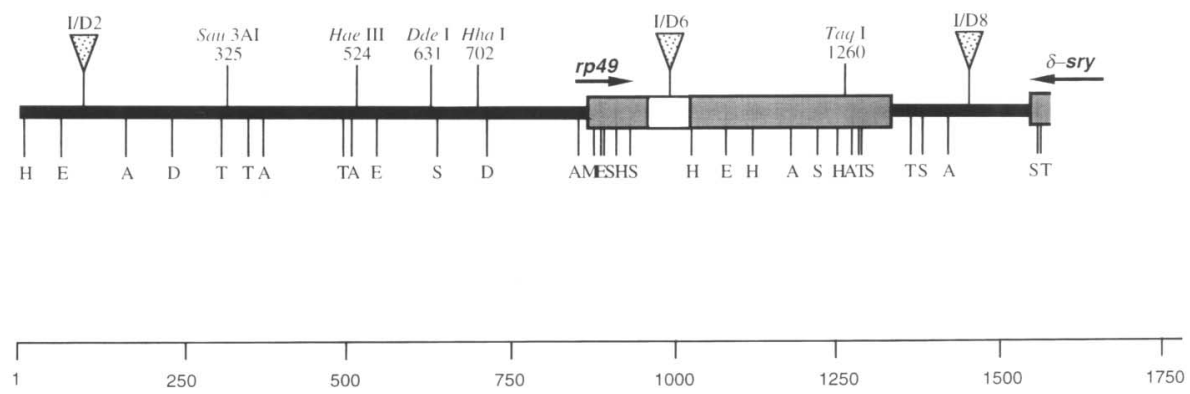

Fig. 1. Restriction map variation of the $r p 4 y$ gene region in a natural population of D. subobscura from Madeira. Polymorphisms are indicated above the horizontal bar: insertions and deletions (I/D) are shown by triangles numbered as in Table 1 and restriction sites by thin vertical bars numbered according to their position in the D. subobscura sequence (Aguadé, 1988). Monomorphic restriction sites are indicated below the horizontal bar. Shaded boxes indicate the $r p 49$ and $\delta$-sry (partial) coding regions and the white box the intron of the rp 49 gene. Arrows show the direction of transcription. 
Table 2. Summary of nucleotide variation at the $r p 49$ region of the D. subobscura population from Madeira.

\begin{tabular}{llrr}
\hline & $\mathrm{O}_{\mathrm{ST}}$ & $\mathrm{O}_{3+4}$ & Total \\
\hline Sample size & 5 & 42 & 47 \\
Restriction-site polymorphisms & 2 & 4 & 5 \\
Number of haplotypes & & 5 & 6 \\
$\quad$ Restriction-site & 3 & 9 & 9 \\
$\quad$ Insertion/Deletion & 3 & 13 & 14 \\
$\quad$ Total & 4 & & \\
h. haplotype diversity & $0.700 \pm 0.218$ & $0.444 \pm 0.089$ & $0.466 \pm 0.085$ \\
$\quad$ Restriction-site & $0.800 \pm 0.164$ & $0.744 \pm 0.061$ & $0.748 \pm 0.056$ \\
Insertion/Deletion & $0.900 \pm 0.161$ & $0.880 \pm 0.032$ & $0.878 \pm 0.032$ \\
$\quad$ Total & $0.0030 \pm 0.0024$ & $0.0018 \pm 0.0017$ & $0.0019 \pm 0.0018$ \\
$\pi$, nucleotide diversity & & & \\
\end{tabular}

be the mechanism generating the different length variants. Length polymorphism I/D6 had 2 variants differing by 5 bp. Length polymorphism I/D8 had 3 variants, the rarest variants differing from the most common one by deletions of 2 and $5 \mathrm{bp}$.

Of the 47 lines analysed, 5 were $\mathrm{O}_{\mathrm{ST}}$ and $42 \mathrm{O}_{3+4}$. For the whole sample a total of 14 haplotypes were detected: 4 in $\mathrm{O}_{\mathrm{ST}}$, and 13 in $\mathrm{O}_{3+4}$ (Tab. 1). Table 2 shows, for each chromosomal gene arrangement, the estimates of haplotype and of nucleotide diversity. However, estimates for $\mathrm{O}_{\mathrm{ST}}$ chromosomes must be taken with caution due to the small sample size. None of the six pairwise comparisons within $\mathrm{O}_{3+4}$ showed significant linkage disequilibrium, neither by the Chi-square nor by the Fisher's exact test (data not shown).

Genetic differentiation between Madeira and other Palearctic populations of $\mathrm{D}$. subobscura

Restriction-site polymorphism from Madeira was compared with data from other Palearctic populations of D. subobscura (Rozas and Aguadé, 1990, 1991a; Rozas et al., 1995). Due to the small sample size of the $\mathrm{O}_{[\mathrm{ST}]}$ chromosomal class in the population from Madeira, only variation within the $\mathrm{O}_{[3+4]}$ chromosomal class was considered. We compared variability in $\mathrm{O}_{|3+4|}$ chromosomal class from Madeira with variation in that chromosomal subsample from Barcelona (Spain), Ter Apel (Holland), El Pedroso (Spain), and Tenerife (Canary Islands, Spain). This comparative analysis was performed for the $1.6 \mathrm{~kb}$ region analysed in all populations; therefore, as a $2.2 \mathrm{~kb}$ region was included in the analysis of previous studies, estimates of nucleotide variation in these European populations were recalculated. Table 3 shows that both the number of polymorphic sites and of restriction-site haplotypes are lower in the Madeira population than in the Barcelona, El Pedroso and Tenerife populations. The population from Ter Apel showed the same number of polymorphic restriction sites (4) and of haplotypes (5) as the population from 
Table 3. Restriction-site variation in $\mathrm{O}_{[3+4]}$ chromosomes.

\begin{tabular}{|c|c|c|c|c|c|}
\hline & \multirow[t]{2}{*}{ Sample size } & \multicolumn{2}{|c|}{ Haplotypic data } & \multicolumn{2}{|c|}{ Polymorphic restriction sites } \\
\hline & & $\mathrm{nh}$ & $h$ & np & $\pi$ \\
\hline Barcelona & 31 & 13 & 0.766 & 9 & 0.00475 \\
\hline Ter Apel & 13 & 5 & 0.705 & 4 & 0.00364 \\
\hline El Pedroso & 140 & 18 & 0.505 & 14 & 0.00275 \\
\hline Madeira & 42 & 5 & 0.444 & 4 & 0.00181 \\
\hline Tenerife & 54 & 8 & 0.495 & 6 & 0.00234 \\
\hline
\end{tabular}

nh, number of haplotypes. $h$, haplotype diversity. np, number of polymorphic restriction-sites. $\pi$, nucleotide diversity.

Madeira, which may be due to the small $\mathrm{O}_{[3+4]}$ sample size of Ter Apel. The low level of nucleotide variation in the population from Madeira is also reflected in the low estimates of nucleotide and haplotype diversity (Tab. 3).

The relationship between restriction-site haplotypes within $\mathrm{O}_{[3+4]}$ was graphically represented by a network, where the most related haplotypes are connected (Fig. 2).

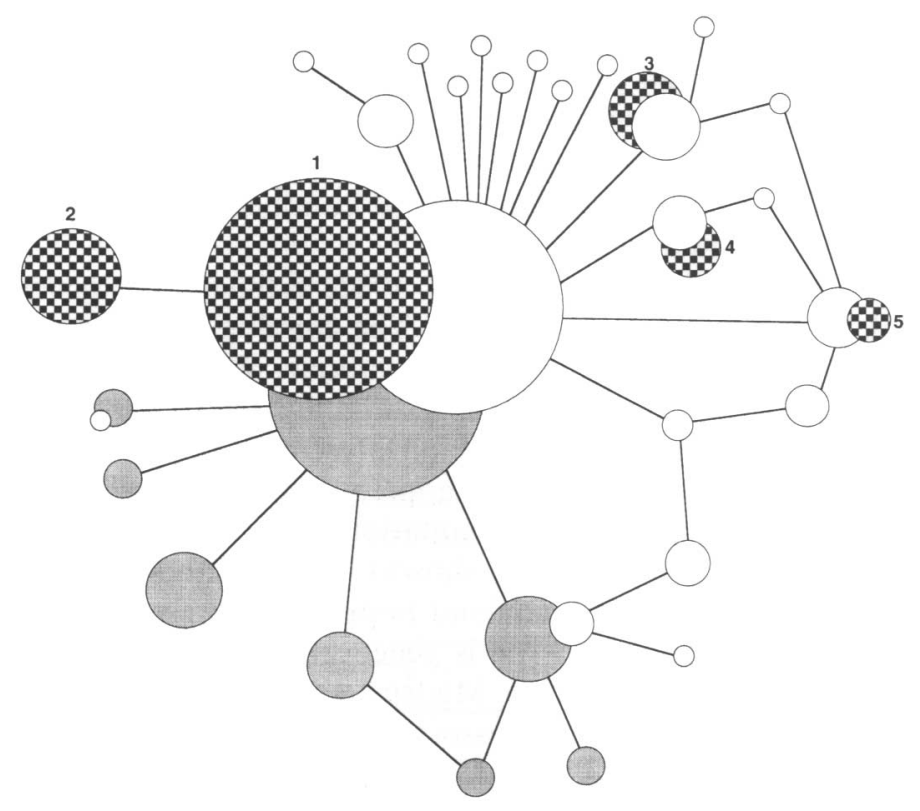

Fig. 2. Network representing the relationship between restriction-site haplotypes of the $r p 49$ gene region within the $\mathrm{O}_{[3+4]}$ chromosomal class. Haplotypes present in continental (Barcelona, Ter Apel and El Pedroso), Canary Islands and Madeira populations of D. subobscura are represented as white, shaded and checkered circles, respectively. Haplotypes present in different populations are represented by superimposed circles. The surface of each circle is proportional to the frequency of each haplotype. Haplotype numbers are as indicated in Table 1 for the Madeira population. 
Table 4. Genetic differentiation betwcen populations

\begin{tabular}{|c|c|c|c|c|c|}
\hline & & Barcelona & Ter Apel & El Pedroso & Madeira \\
\hline Ter Apel & $\begin{array}{l}K_{\mathrm{S}} \\
K_{\mathrm{ST}} \\
P\end{array}$ & $\begin{array}{r}1.182 \\
-0.007 \\
(0.928)\end{array}$ & & & \\
\hline Fl Pedroso & $\begin{array}{l}K_{\mathrm{S}} \\
K_{\mathrm{ST}} \\
P\end{array}$ & $\begin{array}{c}0.833 \\
-0.002 \\
(0.156)\end{array}$ & $\begin{array}{c}0.757 \\
0.001 \\
(0.664)\end{array}$ & & \\
\hline Madeira & $\begin{array}{l}K_{\mathrm{S}} \\
K_{\mathrm{ST}} \\
p\end{array}$ & $\begin{array}{c}0.810 \\
0.031 \\
(0.012)\end{array}$ & $\begin{array}{c}0.605 \\
0.016 \\
(0.089)\end{array}$ & $\begin{array}{c}0.680 \\
0.009 \\
(0.063)\end{array}$ & \\
\hline Tenerife & $\begin{array}{l}K_{\mathrm{S}} \\
K_{\mathrm{ST}} \\
P\end{array}$ & $\begin{array}{c}0.857 \\
0.021 \\
(0.001)\end{array}$ & $\begin{array}{c}0.689 \\
0.033 \\
(0.003)\end{array}$ & $\begin{array}{c}0.704 \\
0.014 \\
(0.003)\end{array}$ & $\begin{array}{c}0.564 \\
0.034 \\
(0.000)\end{array}$ \\
\hline
\end{tabular}

Probability values for genetic differentiation between populations obtained using the Roff and Bentzen test are given in parentheses.

For the analysis, we pooled the three mainland populations (Barcelona, El Pedroso, and Ter Appel) because they are not genetically differentiated within this chromosomal class (Rozas et al., 1995). Four out of the five restriction-site haplotypes present in Madeira were also present in the continental populations with comparable frequencies. The remaining haplotype, which differs from the most common haplotype by the presence of one restriction site (Dde I at position 631 ), is not found in the $\mathrm{O}_{[3+4]}$ lines of the continental populations but it is present in five lines of Madeira.

The UPGMA tree built using $\delta_{\mathrm{st}}$ (Nei, 1982) estimates as genetic distances between populations is shown in Figure 3. The topology of the tree indicates a close relationship among the mainland populations. Table 4 shows the genetic differentiation between populations as measured by the $K_{\mathrm{s}}$ and $K_{\mathrm{st}}$ parameters (Hudson et al., 1992). Putative geographic differentiation among $D$. subobscura $\mathrm{O}_{[3+4]}$ subpopulations was tested by the permutation procedure of Roff and Bentzen (1989) (Tab. 4), and by the permutation method of Hudson et al. (1992) using the test statistic $K_{\mathrm{s}}^{*}$ (results not shown). Both methods show that within $\mathrm{O}_{\left[^{3+4]}\right.}$ chromosomal class: (i) the mainland populations are not genetically differentiated; (ii) the population of Tenerife is genetically differentiated from all other populations; (iii) the population from Madeira shows some differentiation from mainland populations, although the associated probabilities are lower than in comparisons between Tenerife and continental populations.

\section{Discussion}

The present study of nucleotide variation at a single-copy nuclear region, the rp49 region, has revealed that $D$. subobscura from Madeira has less variation than 
continental and Canary Islands populations. If variation at the rp49 region were neutral (see Rozas et al., 1995) and populations were at mutation-drift equilibrium, this lower level of variation would indicate a smaller effective population size in Madeira, consistent with the relatively small area of the Madeira island $\left(730 \mathrm{~km}^{2}\right)$. However, it could also be the effect of the bottleneck suffered by D. subobscura in the colonization of Madeira.

Moreover, this study shows that the population from Madeira is genetically differentiated from continental populations, although in agreement with previous data on allozyme and mitochondrial DNA variation (Larruga et al., 1983; Afonso et al., 1990; Pinto et al., 1997) the degree of differentiation is lower than between Canary Islands and continental populations. In fact, within $\mathrm{O}_{[3,4]}$ only Madeira and Barcelona are significantly differentiated for the $r p 49$ region, while Madeira and both El Pedroso and Ter Apel are marginally differentiated $(0.05<P<0.10)$ (Tab. 4). Additionally, four of the five haplotypes detected within $\mathrm{O}_{[3+4 \mid}$ in the population from Madeira are also detected in this chromosomal class of continental populations (Fig. 2). The population from Tenerife, however, shares three haplotypes with the continental populations while it presents five endemic haplotypes. These differences are reflected in the UPGMA tree based on genetic distances (Fig. 3). The differentiation for the $r p 49$ region between Madeira and Canary Island populations of D. subobscura stands in contrast with data from chromosomal polymorphism. In fact, these insular populations have a reduced chromosomal polymorphism for most chromosomes, and at this level they are differentiated from mainland populations but not among themselves.

Madeira and the Canary Islands, both archipelagos of the Macaronesia, have a volcanic origin and are in rather close proximity to the continent. Nevertheless, they seem to be well isolated from the continent, rarely having undergone colonization events (Francisco-Ortega et al., 1996; Kim et al., 1996; Rozas and Aguadé, $1991 \mathrm{a}$; present study). The major islands of the Canaries arose between 12-21 million years ago (mya) (Carracedo, 1994), while the Madeira islands arose only 5-6 mya (Galopin de Carvalho and Brandão, 1991). Although it would be tempting to speculate that, as compared to Madeira, Canary Islands populations present more endemic haplotypes because of the greater age of the islands, the

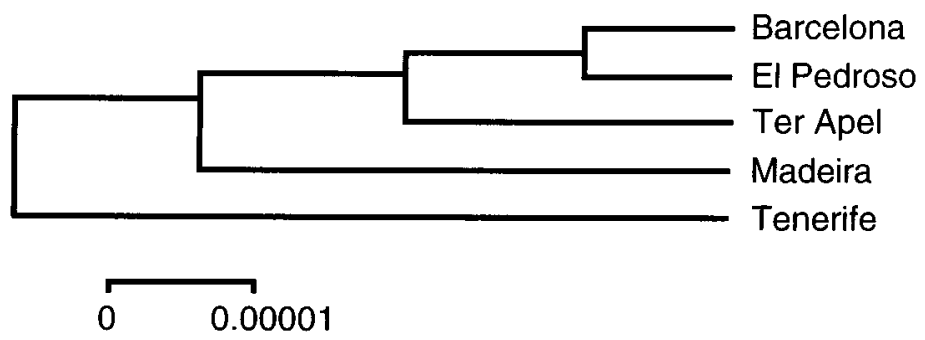

Fig. 3. UPGMA tree showing the relationships between continental and insular populations of $D$. subobscura. The tree is based on $\delta_{s t}$ distances for the $r p 49$ gene region within the $\mathrm{O}_{[3+4]}$ chromosomal class. 
Table 5. Chromosomal arrangements segregating in D. subobscura insular populations and present in the endemic species D. guanche and D. madeirensis.

D. subobscura polymorphism

Chromosomal arrangements of the endemic species ${ }^{\text {i }}$

\begin{tabular}{|c|c|c|c|c|c|c|}
\hline \multicolumn{2}{|c|}{$\begin{array}{l}\text { Chromosomal } \\
\text { arrangements }\end{array}$} & \multirow{2}{*}{$\begin{array}{l}\text { Canary Islands } \\
\text { frequency }^{\mathrm{b}}\end{array}$} & \multirow{2}{*}{$\begin{array}{l}\begin{array}{l}\text { Madeira } \\
\text { frequency }\end{array} \\
11.02\end{array}$} & \multirow{2}{*}{$\begin{array}{l}\begin{array}{l}\text { South Morocco } \\
\text { frequency }\end{array} \\
9.25\end{array}$} & \multirow{2}{*}{ D. guanche } & \multirow{2}{*}{$\frac{\text { D. madeirensis }}{\mathrm{A}_{\mathrm{m} 1+\mathrm{m} 2}}$} \\
\hline A & $\mathrm{A}_{\mathrm{st}}$ & & & & & \\
\hline & $A_{2}$ & 99.42 & 88.06 & 43.39 & & \\
\hline & $\mathrm{A}_{2+6}$ & 0.30 & 0.15 & 25.75 & & \\
\hline & $\mathrm{A}_{2}+3+5+7$ & 0.28 & - & 21.05 & & \\
\hline & $A_{1}$ & - & & 0.53 & & \\
\hline \multirow[t]{2}{*}{$\mathrm{J}$} & $\mathrm{J}_{\mathrm{st}}$ & 1.39 & 13.07 & 2.26 & $\mathbf{J}_{\mathrm{g} 1}$ & $\mathrm{~J}_{\mathrm{st}}$ \\
\hline & $\mathrm{J}_{1}$ & 98.61 & 86.93 & 97.74 & & \\
\hline \multirow[t]{2}{*}{$\mathrm{U}$} & $\mathrm{U}_{1+2}$ & 79.27 & 65.82 & 25.38 & $\mathrm{U}_{1+2}$ & $\mathrm{U}_{1+2}$ \\
\hline & $\mathrm{U}_{1+2+8}$ & 20.73 & 34.18 & 74.62 & & \\
\hline \multirow[t]{7}{*}{$\mathbf{E}$} & $\mathrm{E}_{\mathrm{st}}$ & 14.52 & 24.57 & 8.94 & $E_{\mathrm{g} 1}+\mathrm{g} 2$ & $\mathrm{E}_{\mathrm{st}}$ \\
\hline & $\mathrm{E}_{1+2}$ & 7.77 & 38.95 & 6.30 & & \\
\hline & $E_{1+2+4}$ & 3.33 & 1.66 & 2.60 & & \\
\hline & $\mathrm{E}_{1+2+9+3}$ & 28.42 & 1.27 & 42.14 & & \\
\hline & $\mathrm{E}_{1+2+9+12}$ & 45.95 & 33.45 & 28.40 & & \\
\hline & $E_{1+2+9+4}$ & - & - & 8.19 & & \\
\hline & $\mathrm{E}_{8}$ & - & - & 3.35 & & \\
\hline \multirow[t]{5}{*}{$\mathrm{O}$} & $\mathrm{O}_{\mathrm{s} 1}$ & 0.37 & 5.13 & 1.11 & $\mathrm{O}_{3+\mathrm{g}}$ & $\mathrm{O}_{3}$ \\
\hline & $\mathrm{O}_{3+4}$ & 99.63 & 94.01 & 26.11 & & \\
\hline & $\mathrm{O}_{3+4+2}$ & & 0.86 & $\cdots$ & & \\
\hline & $\mathrm{O}_{3+4+7}$ & - & & 8.97 & & \\
\hline & $\mathrm{O}_{3+4+8}$ & - & - & 63.81 & & \\
\hline
\end{tabular}

"Chromosomal arrangements of $D$. guanche and D. madeirensis are compared to the standard arrangements of $D$. subobscura. $\mathrm{gl}$ and $\mathrm{g} 2$ correspond to inversions only present in $D$. guanche. gc indicates a complex of at least four inversions that are not well characterized. $\mathrm{m} 1$ and $\mathrm{m} 2$ correspond to inversions only present in D. madeirensis (Krimbas and Loukas, 1984).

b Weighted average frequencies of those reported by Prevosti (1974) and Garcia and Prevosti (1081)

situation is not so simple. In each of these archipelagos, one speciation event occurred in the ancestral D. subobscura lineage, which gave rise to $D$. guanche in Tenerife, and to D. madeirensis in Madeira, and both endemic species have the ancestral $\mathrm{O}_{3}$ arrangement. On the other hand, populations of $D$. subobscura from both Madeira and the Canary Islands are nowadays nearly monomorphic for the $\mathrm{O}_{3+4}$ gene arrangement (Tab. 5). Consequently, D. subobscura ancestors should have colonized the islands: i) before the time of divergence of the $D$. guanche and D. madeirensis lineages, which have been dated 1.8-2.8 mya and 0.6-1.0 mya, respectively, from comparison of rp49 sequences (Ramos-Onsins et al., 1998); and ii) after the origin of $\mathrm{O}_{3+4}$ from $\mathrm{O}_{3}$ on the continent, which has been dated between 0.7 and 1.0 mya using sequence information of the rp49 region (Rozas and Aguadé, 1994; Ramos-Onsins et al., 1998). 
Given the time of divergence of the $D$. guanche lineage and of the origin of $\mathrm{O}_{3+4}$ from $\mathrm{O}_{3}$, it is clear that the Canary Islands underwent at least two colonization events from the nearby continent. The first colonizers differentiated in the islands and gave rise to a new species, $D$. guanche. Only after $\mathrm{O}_{3+4}$ had originated in the continent did the second $D$. subobscura colonizers arrive in the Canary Islands and give rise to extant $D$. subobscura insular populations.

The present restriction-map study shows that the D. subobscura population from Madeira is more differentiated from Canary Islands than from continental $\mathrm{O}_{3+4}$ subpopulations. Therefore, the $\mathrm{O}_{3+4}$ carrying colonizers which arrived in Madeira most probably came from the continent and not from the Canary Islands. Also, the divergence of the $r p 49$ sequences of $D$. madeirensis and D. guanche (Ramos-Onsins et al., 1998) clearly indicate that the $\mathrm{O}_{3}$ lineage, which gave rise to $D$. madeirensis, does not derive from the $D$. guanche lineage; this again would indicate that $\mathrm{O}_{3}$ carrying colonizers arrived in Madeira from the continent.

The $r p 49$ data would be compatible with two possible scenarios for the history of Madeira populations: i) two independent colonizations from the continent like in the case of the Canary Islands; in this case D. madeirensis, like D. guanche, would have speciated allopatrically; ii) a single colonization by a continental sample of $D$. subobscura polymorphic for $\mathrm{O}_{3}$ and $\mathrm{O}_{3+4}$; in this case, D. madeirensis could have speciated by microhabitat differentiation. This latter scenario would require the loss of gene arrangement $\mathrm{O}_{3}$ in D. subobscura independently in Madeira and the continent. Therefore, the first scenario with at least two colonizations of Madeira would be more probable; this situation would be similar to that for the Canary Islands. In fact, extant insular populations of D. subobscura present a set of chromosomal arrangements very different from that of the endemic species (Tab. 5). Two samples separated in time from the continent could have carried different sets of chromosomal arrangements, which would easily explain the chromosomal differentiation between the endemic species and D. subobscura, both in the Canary Islands and Madeira. In addition, under the assumption of rare colonization events, the higher genetic differentiation of the populations from the Canary Islands, as compared to Madeira, would indicate a more recent second colonization of Madeira.

Present D. subobscura populations from Madeira and the Canary Islands, although nearly monomorphic for $\mathrm{O}_{3+4}$, are polymorphic for the enzyme loci Lap and Pep; the alleles present in the islands are also present in continental populations. These genes, like $r p 49$, are located on segment $\mathrm{I}$ of the $\mathrm{O}$ chromosome and are therefore affected by inversion $\mathrm{O}_{4}$, which gave rise to gene arrangement $\mathrm{O}_{3+4}$. The unique origin of $\mathrm{O}_{3}{ }_{4}$ from $\mathrm{O}_{3}$ constitutes an extreme bottleneck; in fact, just after its origin, all genes affected by the inversion had zero variation within the new gene arrangement. Therefore, before the second colonization of each archipelago from the continent, this gene arrangement must have accumulated some variation for these loci. Consequently, the second colonization of the islands could not have occurred immediately after the origin of $\mathrm{O}_{3+4}$, but some time after it.

Nowadays natural populations of $D$. subobscura in these archipelagos lack some gene arrangements that are in high frequency in the nearby continent (e.g. $\mathrm{O}_{3+4+8}$, 
Tab. 5). Under the assumption of rare colonization events, this could have both historical and selective causes: i) the second colonization of each archipelago predated the time when these gene arrangements had reached some frequency in the nearest mainland populations; ii) these gene arrangements were present among the colonizers but they were selected against and eliminated in the islands. Present knowledge does not allow discrimination between the historical and selective explanations. An alternative to the assumption of rare colonization events is that physical migration between the continent and the islands was not blocked; in this case, strong selection against arrangements other than $\mathrm{O}_{3+4}$ would be preventing their establishment in the islands. In contrast to allozyme and mtDNA data (Pinto et al., 1997), the pattern of variation at the $r p 49$ gene region does not favor extensive migration between the continent and Madeira. In addition, common colonization events would not explain the clear differentiation of populations from the Canary Islands for mtDNA and for the rp49 gene region.

\section{Acknowledgements}

We thank professor A. Prevosti for critical reading of the manuscript. This work was supported by grant Stride 381/92/c/bio from Junta Nacional de Investigaçao Cientifica e Tecnologica, Portugal to A. B.; by grants PB94-0923 from Dirección General de Investigación Cientifica y Técnica, Ministerio de Educación y Ciencia, Spain and 1995SGR-577 from Comissió Interdepartamental de Recerca i Innovació Tecnològica, Generalitat de Catalunya to M. A., and by Centro de Ciencia e Tecnologia da Madeira to M.K.

\section{References}

Afonso, J. M., A. Volz, M. Hernández, H. Rutthay, A. M. González, J. M. Larruga, V. M. Cabrera and D. Sperlich. 1990. Mitochondrial DNA variation and genetic structure in Old-World populations of Drosophila subobscura. Mol. Biol. Evol. 7: $123 \cdot 142$.

Aguadé, M. 1988. Nucleotide sequence comparison of the rp49 gene region between Drosophila subobscura and D. melanogaster. Mol. Biol. Evol. 5: 433-441.

Carracedo, J. C. 1994. The Canary Islands: an example of structural control on the growth of large oceanic-isiand volcanoes. J. Volcanol. Geotherm. Res. 60: 225-241.

Francisco-Ortega, J., R. K. Jansen and A. Santos-Cabrera. 1996. Chloroplast DNA evidence of colonization, adaptive radiation, and hybridization in the evolution of the Macaronesian flora. Proc. Natl. Acad. Sci. USA 93: 4085-4090.

Galopin de Carvalho, A. and J. Brandão. 1991. Geologia do Archipélago da Madeira. Museu Nacional de História Natural, Universidade de Lisboa.

García, M. P. and A. Prevosti. 1981. Association between allozyme alleles and chromosomal arrangements of the O chromosome in Drosophila subobscura. I. Data of natural populations. Genét. Ibér. 33: $151-174$.

Hudson, R. R., D. D. Boos and N. L. Kaplan. 1992. A statistical test for detecting population subdivision. Mol. Biol. Evol. 9: 138-151.

Kim, S.-C., D. J. Crawford, J. Francisco-Ortega and A. Santos-Guerra. 1996. A common origin for woody Sonchus and five related genera in the Macaronesian islands: molecular evidence for extensive radiation. Proc. Natl. Acad. Sci. USA 93: 7743-7748. 
Kreitman, M. and M. Aguadé. 1986. Genetic uniformity in two populations of Drosophila melanogaster as revealed by filter hybridization of four-nucleotide-recognizing restriction enzyme digests. Proc. Natl. Acad. Sci. USA 83: 3562-3566.

Krimbas, C. B. 1992. The inversion polymorphism of Drosophila subobscura, pp 127-220. In C. B. Krimbas and J. R. Powell (Eds.), Drosophila Inversion Polymorphism. CRC Press, Inc. Boca Raton, Florida.

Krimbas, C. B. and M. Loukas. 1984. Evolution of the obscura group Drosophila species. I. Salivary chromosomes and quantitative characters in $D$. subobscura and two closely related species. Heredity 53: $469-482$.

Kumar, S., K. Tamura and M. Nei. 1994. MEGA: Molecular evolutionary genetics analysis software for microcomputers. Comput. Applic. Biosci. 10: 189-191.

Larruga, J. M., V. M. Cabrera, A. M. González and A. Gullón. 1983. Molecular and chromosomal polymorphism in continental and insular populations from the southwestern range of Drosophila suhobscura. Genetica 60: 191-705.

Latorre, A., A. Moya and F. J. Ayala. 1986. Evolution of mitochondrial DNA in Drosophila subobscura. Proc. Natl. Acad. Sci. USA 83: 8649-8653.

Levinson, $G$. and $G$. A. Gutman. 1987. Slipped-strand mispairing: a major mechanism for DNA sequence evolution. Mol. Biol. Evol. 4: 203-221.

Lewontin, R. C. 1964. The interaction of selection and linkage. I. General considerations: heterotic models. Genetics 49: 4967.

Nei, M. 1982. Evolution of human races at the gene level, pp 167-181. In B. Bonne-Tamir, T. Cohen, and R. M. Goodman (Eds.), Human Genetics, Part A: The Unfolding Genome. Alan R. Liss, New York.

Nei, M. 1987. Molecular Fvolutionary Genetics. Columbia University Press, New York.

Nei, M. and F. Tajima, 1981. DNA polymorphism detectable by restriction endonucleases. Genetics 97 : $145-163$.

Pinto, F. M., A. Brehm, M. Hernández, J. M. Larruga, A. M. González and V. M. Cabrera. 1997. Genetic structure and colonization sequence of the Atlantic islands of Canaries and Madeira populations of Drosophila subobscura inferred by autosomic, sex-linked and mtDNA traits. J. of Heredity 88: $108-114$.

Prevosti, A. 1972. Chromosomal polymorphism in Drosophila subobscura populations from the Madeira island. Genét. Ibér. 24: 11-21.

Prevosti, A. 1974. Chromosomal inversion polymorphism in the southwestern range of Drosophila suhobscura distribution area. Genetica 45: 111-124.

Prevosti, A., G. Ribó, L. Serra, M. Aguadé, J. Balañá, M. Monclús and F. Mestres. 1988. Colonization of America by Drosophila subohscura: Experiment in natural populations that supports the adaptive role of chromosomal-inversion polymorphism. Proc. Natl. Acad. Sci. USA 85: 5597 5600 .

Prevosti, A., I. Serra, C. Segarra, M. Aguadé, G. Ribó and M. Monclús. 1990. Clines of chromosomal arrangements of Drosophila subobscura in South America evolve closer to Old World patterns. Evolution 44: $218 \cdot 221$.

Kamos-Onsins, S., C. Segarra, J. Rozas and M. Aguadé. 1998. Molecular and chromosomal phylogeny of the obscura group of Drosophila inferred from sequences of the rp49 gene region. Mol. Phylogenet Evol. 9: 33-41.

Roff, D. A. and P. Bentzen. 1989. The statistical analysis of mitochondrial DNA polymorphisms: $\chi^{2}$ and the problem of small samples. Mol. Biol. Evol. 6: 539-545.

Rozas, J. and M. Aguadé. 1990. Evidence of extensive genetic exchange in the $r p 49$ region among polymorphic chromosome inversions in Drosophila subobscura. Genetics 126: 417-426.

Rozas, J. and M. Aguadé. 1991a. Study of an isolated population at the nucleotide level: $r p 49$ region of a Canarian population of Drosophila subobscura. Mol. Biol. Evol. 8: 202-211.

Rozas, J. and M. Aguadé. 1991b. Using restriction-map analysis to characterize the colonization process of Drosophila subobscura on the American continent. I. rp49 region. Mol. Biol. Evol. 8: 447-457. 
Rozas, J. and M. Aguadé. 1993. Transfer of genetic information in the rp49 region of Drosophila subobscura between different chromosomal gene arrangements. Proc. Natl. Acad. Sci. USA. 90: $8083-8087$.

Rozas, J. and M. Aguadé 1994. Gene conversion is involved in the transfer of genetic information between naturally occurring inversions of Drosophila. Proc. Natl. Acad. Sci. USA. 91: 1151711521.

Rozas, J., C. Segarra, C. Zapata, G. Alvarez and M. Aguadé. 1995. Nucleotide polymorphism at the rp49 region of Drosophila subobscura: Lack of geographic subdivision within chromosomal arrangements in Europe. J. evol. biol. 8: 355-367.

Sperlich, D., H. Feuerbach-Mravlag, P. Lange, A. Michaelidis and A. Pentzos-Daponte. 1977. Genetic load and viability distribution in central and marginal populations of Drosophila subobscura. Genetics 86: 835-848.

Received 20 December 1996; accepted 25 April 1997.

To access this journal online:

(20) http://www.birkhauser.ch 